\title{
Challenges Facing Future Housing Policy ${ }^{1}$
}

\author{
RIITTA AUVINEN \\ Senior Research Associate, Docent \\ The Population Research Institute of Väestöliitto \\ Helsinki, Finland
}

\begin{abstract}
Since World War II the housing policy in Finland has been effective enough to reach the minimum norm for family dwellings set by IUFO presuming that occupants have the use of one room per person. From now on Finland ought to concentrate the building resources on bigger and better quality housing. The remaining housing base including mainly small apartments could then be used for young people who can be defined "homeless" by the new standards of housing. There is a slight evidence that the birth rate could be raised by the housing policy because of an attitudinal readiness in Finland for raising the number of children and level of housing.
\end{abstract}

Keywords: housing, housing policy, Finland

\section{Introduction}

As a result of the economic depression, a stillness is reigning over the housing sector in Finland. This could be a creative silence, for now we have time to consider housing aims and possible new directions to take in our country. At the least we now have the opportunity to look backward to see how far we have come and to gather facts as a starting point from which to proceed.

Lately it has often been said that there is nothing left to be built in Finland. The majority of the people in our nation already have fair housing and only a special small group, slightly over ten thousand people, are classified as homeless and need special measures to improve their housing situation. Citing these views, the activities of housing policy officials have been curtailed and some housing bureaus previously funded by the state have actually been closed down.

"The ongoing violent changes and shifts in emphasis have to a great extent undermined the available estimates concerning long-term in the housing sector. For this reason Finland does not have a sufficient information base on which the strategic development of the housing sector could occur" (Kivistö 1993, 280).

Our country's population development in itself has proved to be a factor pointed to as a reason for at least partially dismantling our housing policy. According to the estimates, the Finnish population will reach its peak soon after the year 2000 and then

${ }^{1}$ I am indebted to Anneli Miettinen for the data processing of this article. 
begin to decline, so it is hard to find any special reasons for increasing housing in Finland.

The focus lately has been more on new demands concerning the housing structure, now that the elderly are forming a growing proportion of the population and elderly inhabitants set special demands on housing. Less visible has been any consideration of how housing policy and housing decisions in themselves can influence population development. Is there perhaps a hidden vicious circle in Finnish housing policy which in itself causes the population to diminish by, for example, decreasing the birth rate?

Finland does not form a separate insular area of its own in housing construction, instead it fits into the map of Europe and its own surroundings in a manner that has led to it customarily being compared to the other countries of Western Europe. With pride in our past housing production, we can note that this construction has occurred at a truly rapid rate and that we have to a great extent closed the gap between our housing culture and that of Western Europe, a gap which was still visible to the eye after the Second World War. The high level of production has raised our housing level so it is fully comparable with most European countries. We have 434 dwellings per thousand inhabitants, while Sweden, a leading country, has 462 (Lujanen 1993, 258).

\section{Background to the research}

Statistics Finland gathered extensive questionnaire data in 1989, which also included some questions related to housing. ${ }^{2}$ These questions, originally meant as supplementary ones, are interesting in regard to certain background variables. They give quite a representative picture of features relating to the housing of the population, although from a woman's point of view. If we remember to bear this "unusual" viewpoint in mind, there is nothing to prevent us from seeing the results as a portrayal of how Finnish families live.

By cross-tabulating the above information with basic variables concerning the interviewee, such as age, household size and number of siblings in the childhood family, we can try to find interesting and significant relationships in the housing of the Finnish female population and thus of Finnish families. The "roots" of housing can be explored with an examination of moves to new dwellings, how young people detach themselves from the childhood home and the relationship between family risks and moving. When, in addition, the interview provides us with information about the number of births and plans for having children, it is also possible to try to examine the relation between housing and the birth rate.

${ }^{2}$ The statistics Finland data was composed originally of 5,105 women who at the time of the interview were 21-51 years old. The interviewees were chosen for the sample by random sampling from the Statistics Finland Population Statistics. Of the original sample, 4,155 women were ultimately interviewed. Thus the loss was $18.6 \%$ or 950 women. The loss percentage was highest in Helsinki, where it was $39 \%$. The most common reason was refusal $(84 \%)$. A more thorough analysis of the sampling design and loss was made by Statistics Finland (Väisänen 1992, 169-172). The reliability of the results has also been analyzed (Nikander 1992, 15-16).

In the interview, the following questions were among those concerning housing. Did the respondent live with both biological parents at the age of 14 , and if not, why? In what kind of a community did the interviewee live during her childhood? How many times did she have to move as a child and did the family have long-term economic difficulties? Has the interviewee moved away from her parents' home, at what age and what was the reason for moving away? How many rooms are there in the current dwelling and what is its area? How many persons moved into the current dwelling and who owns it? It is also possible to obtain information about the number of moves occurring during adulthood. 


\section{Families and the current standard of housing}

In the current housing statistics we can see a trend, which still shows the historic housing tradition in Finland after the Second World War. We have constructed a lot and at great speed, but always with very scanty resources and therefore dwellings that are too small. As a result, the average Finns continue to live in quite small dwellings and especially if we have a family, we have to manage with less than the European standard of space. And because the housing tradition is poor - some of our own grandparents still lived as dependent lodgers - we are not even aware that in our own housing demands we could identify with the practice already existing in countries more advanced than ours. This is apparent, for example, in our continuing to build small housing, which in the future may easily become a burden to us.

As the established size of a household in our housing market is already small, it can no longer be used to classify various types of families in regard to housing demands. The deviation from the basic standard is too small for families of different sizes to be taken into consideration concerning housing need and, for example, for current large family households, e.g. those with three or more children, to have an impact on housing planning. Thus the danger exists that with rising expectations concerning the housing standard, the housing base, which consists of dwellings that are too small, will ultimately wipe away all those families still left which have more than two children and, at the least, will in no way advance the future birth rate. As the already existing housing base is supposed to serve for several decades to come, in the housing market construction which is directed only by demand will easily lead to construction which is wrong for us and, in the long run, untenable and which will even turn into a future burden.

A concurrent perusal of both housing and population statistics already demonstrates, in my opinion, that, in the future, Finland should produce less housing than before, and instead bigger and better quality housing, so that in the future there will be continued healthy development in our housing. In the next section I will try to explain this viewpoint more closely. In addition, I will examine other statistically significant research results relating to housing found in this data.

\section{Dwelling size among the families in the study}

In examining housing, the size of the household is a central factor to be considered. The allotment of space in a dwelling depends on the number of persons living in the household. We know that the Finnish family has continually grown smaller and that therefore its housing needs have changed. This decrease in size is apparent in the data we have about the number of persons in the household, which in 86.9 percent of the cases was at most four persons. Thus, already nine households in ten in need of and searching for a dwelling are composed of at most of a small family with a father, mother and two children. The remaining minority and thus a minority which is apparently a problem in the housing market is formed by about one tenth of the households, which are bigger than this and do not fit the small family model already prevailing in Finland.

The transition in Finnish housing has been rapid and sharp. Therefore, awareness of the change has come well after the fact and has not led to necessary changes in thinking and conclusions about its consequences for housing policy. Typical of this change, which has occurred within the span of one generation, is that the childhood families of slightly under one half of the $22-51$ year olds interviewed in our data included four or more siblings. There has been a steep decrease from the large family of the previous generation to the small family of today. 
In the research data, the current dwelling of over one half of the interviewees $(55.9 \%)$ contained three rooms at most, without counting the kitchen as a room. Four fifths of those interviewed fitted into the "maximum of four rooms" housing category, the housing minimum of the average Finnish family of a father, mother and two children. Thus, with the diminishing of family size, Finnish households are gradually reaching the minimum norm for family dwellings set by the International Union of Family Organizations (IUFO) in the 1950 s, which presumes that occupants have the use of one room per person.

When the area of the dwelling was used to measure the housing standard, it was again shown that, on the average, the interviewees live in small dwellings, in other words in the existing housing which has been produced in this country during the last few decades. One third lived in at most a 70-square-meter dwelling and one half in at most 80 square meters. If the ARAVA dwelling maximum of 120 square meters - the maximum size of dwelling which justifies to receive state ARAVA loans - is considered a point where luxury begins in Finland, this limit was exceeded by only $15 \%$ of those interviewed.

As already one half of those interviewed had set their housing norm at over 80 square meters, we can conclude that even though families are getting smaller, efforts will be made to raise the housing standard, so that more people could live in a home of over 80 square meters in area. Because traditionally housing in Finland has been based predominantly on small dwellings, future housing construction should, in order to satisfy the challenges of future housing, concentrate only on building large dwellings exceeding 80 square meters in area, so that housing now and in the future could take place in accordance to the European norms already adopted by the people.

As we know that housing decisions have their own impact on family formation and assumedly also on the birth rate, our thinking should be based on the view that the already existing housing base will be able to satisfy at least the major need for other than family dwellings. Thus the minimum size of a family dwelling, in Finland at least 80 square meters, should be the starting point for new construction, so that there should be no special problems in satisfying future housing needs. In the research data we are examining, this appears to have already become the minimum goal of Finnish families in light of the current demand. At the same time this would apparently meet the needs of larger than average households, which now carry only a little weight (ten percent) in influencing demand.

\section{Young people and housing}

In Finland homeownership is common compared to other European countries. One could almost say that Finland is a nation of homeowners and that our society is a "homeowner society" (Juntto 1993, 160). In this data, two thirds of the persons interviewed lived in their own home. In order to guarantee that housing will be flexible also in the future, there is probably no cause to raise the level of homeownership. However, satisfaction with the high level of home ownership may conceal certain problems. It has been said that the innocent victims of homeownership in Finland are the young, who are not able to break away until relatively late from the nest their parents have built and saved up for.

The parents, because of their own financial situation, either cannot or do not want to help their children acquire a home of their own nor do they want to see the family home they have finally gained to be empty right away.

According to the official statistics, there are about 12,000 homeless people in Finland. However, when counting the homeless, the result naturally depends on how home- 
lessness is defined. Lately, the current official definition has been questioned by Nuorisoasuntoliitto (Union for Youth Housing in Finland), among others. This association has defined as homeless also those young people over the age of 18 who are living in their childhood home (the policy stand of the Union for Youth Housing in Finland, May 1993).

In some European countries, in Sweden for example, the relative number of the homeless is higher than in Finland, because in these countries young adults living with their parents are already defined as homeless. Calculated in this way, the number of homeless in Finland is substantially greater than in the official statistics. According to a calculation made by the Union for Youth Housing in Finland, if thus defined, there are about 105,000 homeless in Finland (Lankinen 1990, 3).

In Finland a young person reaches maturity at the age of 18. She or he is then considered a responsible member of our society. However, in many social dimensions such as in education, economy and especially in housing, the young are not yet able to realize this full responsibility. Their dependence on society and on their parents continue to be too great for this to happen.

In families following a normal course of life, children usually leave the parents' home when they are moving to another locality to go to college or take a course, are entering employment or are starting their own family. In this research data, in four out of five cases, the normal reaching of adulthood ended the phase when children lived with their parents. Only $3 \%$ of those interviewed had finally remained at home and were living with their parents. In addition, one interviewee in five had not been living with both biological parents at the age of 14 , because of various family risks. We will return to these cases later.

The main reason for leaving the childhood home was to form a relationship, either a marital union or a consensual union, in all $38.3 \%$. One fourth of the young women had left in order to begin a course of studies, and work had detached $21 \%$ from their childhood home. The others explained leaving home as a desire to become independent $(10.7 \%)$ or gave some other reason.

Thus more than one third of the girls went directly from their parents' home to living in a new home with a partner, without first experiencing a phase of independence. In the whole data the proportions entering a marriage or a consensual union were about even, for $20 \%$ left the parents' home for marriage and $18.3 \%$ for a consensual union. In the younger age groups the proportion entering a consensual union increases.

Certain phases of maturation belong to the human life course, phases when a person, in this case a young woman, sets new goals in her life. The possibility to set these goals, as well as to attain them at the right time, is a prerequisite for natural, healthy development. This also concerns gaining independence from one's parents and detachment from the parental home. If there is no opportunity for independence, if, for example, housing policy decisions are not as flexible as they should be, healthy development will be disturbed. Dependence on the parental home and continuing to live with the parents can be a strain to both sides.

In the data we are examining, detachment culminates at the age of 19. At this age, the majority of those interviewed had already moved away from their parents' home. One third had already left home a year earlier and among the 20 year olds already two thirds had left home. Nine out of ten had moved away from home by the age of 25 . We already noted earlier that only about three women out of one hundred had ended up as a "mama's girl".

Although the respondents are women, the conclusion can still be drawn on the basis of these interviews that there really is a hidden housing need among the young age groups in our country, a need which has not been fulfilled because of a lack of suit- 
able resources. Considering a young person's future, it is probably not a favorable situation, for example, when over one third of the women are leaving the parents' home for marriage or consensual union, without going through a phase of independence.

One could even suspect that consensual unions, especially, are considered the only means to detach oneself from the parents' home, if young people are ready for this detachment and no other means are available. On the other hand, it is also likely that living in the parents' home interferes with the normal formation of relationships and detaching oneself from the home and then having one's first child will be postponed to a late age or forever. Similarly, living in a consensual union probably postpones having the first child, puts off family formation to a later date and thus indirectly decreases the birth rate.

In this data, $85 \%$ of the persons interviewed who lived with a partner were living in their first union. Of these, $55.3 \%$ had first chosen a consensual union, while $44.7 \%$ had entered directly into marriage. The younger the age group, the more often the first union is a consensual union (Nikander 1992a, 13). It is probable, even though not specifically clarified in the questionnaire, that a partial explanation for the frequency and increase in choosing a consensual union is in the economic situation young people are in and in taxation considerations. In Finland, the right to a tax deduction for interest on a housing loan has a favorable impact on the formation of consensual unions, not on that of marriages. This right to deduct interest is now one of the most effective official resources available in housing policy that young people can use for their housing needs.

When it is readily apparent that there is a housing need among the young, caused by the pressure to gain independence, and that their resources in the early stages of their lives are generally poor, the housing demands of young people appear to focus especially on small dwellings. Therefore, considering the future, the distribution of the Finnish housing base should be planned so that it will support young people by directing already existing small housing to the needs of young people. In this way, the small dwellings now below the housing standards for family housing would gradually find new use and the housing base would be able to renew itself sensibly without waste.

Housing support measures, which up to now have been biased toward the construction of new housing, should, when planning for young people, be directed toward the use of existing housing. Expensive and strength taxing housing construction in this northern climate would thus be directed also by future demands and not just by shortsighted, poor demands.

As homeownership is common in our country and the actual life task of today's working-age generation has been to save for their own home, the current generation's parents have had no opportunity to support their children in obtaining housing, especially not when there have been several children in the family. Nevertheless, young people have the will and generally are also gradually gaining the resources to arrange their housing according to their own needs.

Thus a definite challenge facing Finnish housing policy is in how to support the housing of young people, who are gradually becoming independent, in already existing housing, so that small dwellings would be transferred to the young and the production of new housing would focus on larger family dwellings. Thus the entire population's housing standard would be raised by producing less than before, but larger and better quality dwellings. By making young people independent earlier and thus also offering families a higher standard of housing, these measures could also lead to a rise in the birth rate. 


\section{The "roots" and risks of housing}

The financially most significant housing benefit in Finland in the last few decades has been the right in taxation to deduct interest on housing loans, which has gradually, over the years, become a means for the average citizen to increase his or her capital, i.e. the root of Finnish "everyday capitalism". It can even be considered to have led to a social rootlessness among some families with continuously changing housing environments. When the previous debt is paid up, a new loan has been acquired, with which to move to a new home, in order that one's taxable income can be reduced by the amount deductible for interest on a debt. Unfortunately, the possible effect on moving of the right to a tax deduction for interest on housing loans was not included in the questionnaire, so that an estimate of its specific effect on housing moves cannot be made.

On the other hand, there were questions about the number of moves during childhood, under the age of 15. Two thirds of those interviewed had not moved even once during their childhood. In areas of dispersed settlement, four out of five had lived in the same home throughout their childhood. The majority of the Finnish adult population, those aged $22-51$, thus continue to have definite roots in their childhood environment. Only slightly over ten percent of those who had lived in an urban area or a built-up area had experienced three or more moves during their childhood (Table 1) ${ }^{3}$.

A large family also appears to be the result of permanent housing. (Table 2). In families with seven or more siblings, four out of five had not moved even once, while

T a b l e 1. Number of moves in childhood and place of residence in childhood

\begin{tabular}{lcccccr} 
& \multicolumn{7}{c}{ Number of moves } \\
& 0 & 1 & 2 & 3 & $4+$ & Total \\
Urban center & 58.1 & 19.9 & 9.3 & 6.7 & 6.1 & 13.0 \\
Suburb & 58.2 & 20.1 & 8.3 & 6.9 & 6.4 & 20.6 \\
Municipal center & 57.1 & 20.8 & 7.4 & 6.5 & 8.2 & 11.5 \\
Other built-up area & 64.0 & 18.8 & 7.3 & 4.5 & 5.4 & 16.1 \\
Area of dispersed & & & & & & \\
settlement & 78.9 & 12.4 & 3.9 & 2.5 & 2.3 & 38.8 \\
Total & 67.0 & 17.0 & 6.5 & 4.7 & 4.8 & 100.0 \\
$\mathrm{~N}=4147$ & & & & & &
\end{tabular}

T a b l e 2. Number of siblings and number of moves in childhood

Number of moves

$\begin{array}{lcccccr}\begin{array}{l}\text { Number of } \\ \text { siblings }\end{array} & 0 & 1 & 2 & 3 & 4+ & \text { Total } \\ 1 & 61.0 & 21.0 & 7.6 & 3.8 & 6.6 & 10.2 \\ 2 & 60.9 & 19.6 & 8.5 & 5.9 & 5.1 & 20.4 \\ 3 & 62.8 & 18.9 & 6.8 & 5.8 & 5.6 & 21.9 \\ 4 & 67.8 & 16.3 & 5.8 & 5.2 & 4.9 & 16.1 \\ 5 & 73.7 & 12.9 & 6.0 & 4.4 & 3.0 & 10.4 \\ 6 & 72.3 & 14.9 & 5.4 & 4.1 & 3.4 & 7.1 \\ 7+ & 79.0 & 11.6 & 3.6 & 1.9 & 3.8 & 13.9 \\ \text { Total } & 67.1 & 16.9 & 6.5 & 4.7 & 4.8 & 100.0 \\ \mathrm{~N}=4154 & & & & & & \end{array}$

\footnotetext{
${ }^{3}$ The association between the variables has been significant on a level of at least 95 percent in all the tables included.
} 
among families with two children there were fewer who had not moved at all, two out of three. As the childhood family grew the tendency to move, or should one say, the possibility to move systematically decreased. In this data, which included people up to middle age, the rural background of childhood still probably explains the few moves there were in all. It should be mentioned that in this data, "genuine rural people" or women who in their childhood had lived outside built-up areas still totaled $38.7 \%$.

Long-term economic difficulties in childhood were mentioned by one out of four of those interviewed (Table 3). At least in the younger age groups, housing debts and the right to a tax deduction for interest on these debts may partially explain the correlation between economic difficulties and an increased number of moves.

Housing moves have traditionally been used to measure the unfixedness of life and a large number of moves has been considered a measure of social disorganization. The number of moves experienced in childhood grows, compared to other children, among those who did not live with both biological parents at the age of 14 (Table 4). Some of the children end up being pushed around in the housing market. In the entire data, $18.2 \%$ had not been living with both biological parents at the age of 14 . Thus their families had faced some social risk affecting housing.

Among families which had broken up during childhood, where one biological parent was missing, in 37.7 percent the father had died, in 35.3 percent there had been a divorce, in 9.7 percent the mother had died and in 1.2 percent both parents had died. In the rest of the families, the reason the family broke up was some other cause, such as adoption or a foster-child relationship. The total number experiencing a family risk during childhood among the 4,155 persons interviewed was 755 . For these interviewees, life's beginnings have thus deviated from the family life of others as a result of a social risk facing their family life.

The data provides an opportunity to examine the effect of childhood family risk on the later life of the interviewee and her housing history. Is there a certain significance for adult life in the childhood family having broken up or that the childhood family had at most one biological parent?

$\mathrm{T}$ a b l e 3. Economic difficulties in childhood and number of moves in childhood

\begin{tabular}{|c|c|c|c|c|c|c|}
\hline \multirow[b]{2}{*}{$\begin{array}{l}\text { Economic } \\
\text { difficulties }\end{array}$} & \multicolumn{5}{|c|}{ Number of moves } & \multirow[b]{2}{*}{ Total } \\
\hline & 0 & 1 & 2 & 3 & $4+$ & \\
\hline $\begin{array}{l}\text { Yes } \\
\text { No }\end{array}$ & $\begin{array}{l}63.0 \\
68.4\end{array}$ & $\begin{array}{l}18.1 \\
16.7\end{array}$ & $\begin{array}{l}8.6 \\
5.8\end{array}$ & $\begin{array}{l}6.0 \\
4.4\end{array}$ & $\begin{array}{l}4.3 \\
4.8\end{array}$ & $\begin{array}{l}24.1 \\
74.0\end{array}$ \\
\hline $\begin{array}{l}\text { Total } \\
\mathrm{N}=4075\end{array}$ & 67.1 & 16.9 & 6.5 & 4.7 & 4.8 & 100.0 \\
\hline
\end{tabular}

$\mathrm{T}$ a b l e 4 . Did the respodent live at the age of 14 with both biological parents and number of childhood moves

\begin{tabular}{lcccccr} 
& \multicolumn{7}{c}{ Number of moves } \\
$\begin{array}{lcccc}\text { Lived with } \\
\text { both parents }\end{array}$ & 0 & 1 & 2 & 3 & $4+$ & Total \\
$\quad$ Yes & 69.7 & 16.1 & 5.8 & 4.1 & 4.4 & 81.8 \\
$\quad$ No & 55.5 & 20.7 & 9.4 & 7.5 & 6.9 & 18.2 \\
Total & 67.1 & 16.9 & 6.5 & 4.7 & 4.8 & 100.0 \\
$\mathrm{~N}=4154$ & & & & & &
\end{tabular}


Ownership in Finnish society has usually been considered a measure of certainty and security in life. The ownership of the interviewee's current dwelling is affected by the "social inheritance" from childhood, because it was more common for the interviewee to own the home she was living in now, if she had been living with both biological parents at the age of 14 (Table 5). Carrying out the Finnish "life task", gaining ownership of one's own home, was more successful for those who had been provided with a sturdy and secure start for this task already in childhood.

Similarly, a difference arose between the size of the current dwelling and the unity of the childhood family (Table 6). The difference was especially apparent in those who had attained a dwelling of over 100 square meters. If the childhood family breaks up, there is weaker provision for life in the future, if this provision is estimated with the level of housing. A child from a broken family does not attain large dwelling or homeownership as easily as one who has lived in a more secure family. Here it has not been possible to examine the possible effect of monetary inheritance on the level of housing.

Living elsewhere as a child than in a family with both biological parents is reflected also in other life course events such as relationships formed as an adult and the number of marriages or consensual unions. Those interviewees who had not been living with both biological parents at the age of 14 , had as an adult lived in more unions than the others (Table 7). Among those who had lived with both parents, $76.8 \%$

$\mathrm{T}$ a b l e 5. Did the respodent live at the of 14 with both biological parents and ownership of current dwelling

Current dwelling

$\begin{array}{lccr}\begin{array}{l}\text { Lived with } \\ \text { both parents }\end{array} & \text { Own } & \text { Not own } & \text { Total } \\ \quad \text { Yes } & 68.9 & 31.1 & 81.8 \\ \quad \text { No } & 64.2 & 35.8 & 18.2 \\ \text { Total } & 68.1 & 31.9 & 100.0 \\ \mathrm{~N}=4155 & & & \end{array}$

$\mathrm{T}$ a b 1 e 6 . Did the respodent live at the age of 14 with both biological parents and size of current dwelling (in square meters)

Size of the dwelling (in square meters)

$\begin{array}{lcccccccr}\begin{array}{l}\text { Lived with } \\ \text { both parents }\end{array} & -20 & 21-55 & 56-70 & 71-80 & 81-100 & 101-120 & 121+ & \text { T } \\ \quad & 1.1 & 17.8 & 16.1 & 14.7 & 16.8 & 18.0 & 15.5 & 81.8 \\ \quad \text { Yes } & 0.7 & 19.5 & 20.7 & 15.2 & 19.2 & 13.8 & 11.0 & 18.2 \\ \quad \text { No } & 1.0 & 18.1 & 16.9 & 14.8 & 17.2 & 17.3 & 14.7 & 100.0 \\ \quad \begin{array}{l}\text { Total } \\ \mathrm{N}=4153\end{array} & & & & & & & & \end{array}$

$\mathrm{T}$ a b l e 7. Did the respodent live at the age of 14 with both biological parents and number of unions respodent has had

Lived with both parents

Yes

No

Total

$\mathrm{N}=4155$

\begin{tabular}{ccccc}
\multicolumn{5}{c}{ Number of unions } \\
0 & 1 & 2 & $3+$ & Total \\
11.0 & 76.8 & 10.6 & 1.7 & 81.8 \\
10.1 & 71.7 & 15.1 & 3.2 & 18.2 \\
10.8 & 75.8 & 11.4 & 2.0 & 100.0
\end{tabular}


had lived in only one union. For others this same figure was 71.7. The corresponding percentages are 10.6 and 15.1 for those who had experienced two unions and 1.7 and 3.2 percent for those with three or more unions, calculated from the entire data. The life model inherited socially and one's own social unfixedness appears to be carried along into adulthood.

Regarding the special housing problems of the future, it appears that there is a certain predictive value to having lived with both biological parents in one's childhood. If we wish to base housing policy on a survey of special groups, which might possibly need intensive measures in order that their housing needs could be realized and that they could attain the standard already reached by the rest of the population, more attention should be paid in the future to people who have experienced family risk in childhood. The death of one biological parent or his or her loss through divorce appears to be reflected in the child's housing and way of life far into the future.

\section{Housing and having children}

The data also provides an opportunity to examine the relation between housing and having children, because it included a total of 2,225 women under 40 , or of childbearing age, on whom information was available. Finnish women still usually wish to have children and assumedly housing experiences are significant regarding how many children they are going to have. There are, of course, other aims in the lives of young people besides having children, of which obtaining one's own dwelling is not the least. But even if these goals are often contradictory, they still are not or should not be mutually exclusive.

An interesting interview result, in light of the goals in one's own life, is the effect childhood family experiences have on the forming of one's own family. It shows that the more siblings there were in the interviewee's childhood family, the more vague the plans to have children are (Table 8 ). When only $9.4 \%$ of the women who had seven or more siblings in their childhood family give a definite "yes" to whether they plan on having children, the corresponding percentage for those who had grown up in two-child families was 28.6. At least one explanation for the statistically significant correspondence between the number of siblings in the childhood family and one's own plans to have children could be experience as a child of having to live in close quarters and the discomfort of life in a large family, of which the respondent is already aware through personal experience.

The kind of dwelling one lives in and the security of housing conditions do not appear to be insignificant factors in regard to having children and the birth rate. Even

T a b le 8 . Number of siblings and respodent's plans to have children

Does she plan to have children

\begin{tabular}{lccrrrr}
$\begin{array}{l}\text { Number } \\
\text { of siblings }\end{array}$ & $\begin{array}{c}\text { Information } \\
\text { missing }\end{array}$ & \multicolumn{1}{c}{ Yes } & Maybe & No & $\begin{array}{l}\text { Don't } \\
\text { know }\end{array}$ & Total \\
1 & 44.2 & 23.4 & 10.9 & 18.2 & 3.3 & 10.1 \\
2 & 38.0 & 28.6 & 11.8 & 16.9 & 4.7 & 20.4 \\
3 & 43.7 & 23.9 & 10.8 & 16.4 & 5.2 & 21.9 \\
4 & 45.2 & 21.6 & 10.0 & 19.3 & 3.9 & 16.1 \\
5 & 51.4 & 14.1 & 8.8 & 19.1 & 6.7 & 10.4 \\
6 & 55.1 & 11.5 & 10.5 & 18.6 & 4.4 & 7.1 \\
$7+$ & 58.1 & 9.4 & 8.1 & 19.9 & 4.5 & 13.9 \\
Total & 46.5 & 20.5 & 10.3 & 18.1 & 4.7 & 100.0 \\
N = 4155 & & & & & &
\end{tabular}


though living in too small a dwelling did not appear to have any explanatory value in the entire data, when asking for the most important reason why the interviewee did not want (any more) children (Nikander 1992, 95), we should perhaps define the possible correspondence between the housing situation and having children in those age groups, which are still bearing children and who, in practice, can influence the birth rate.

Life goals are reflected in the number of housing moves occurring in adulthood. Moves which have occurred after the age of twenty tell in very concrete terms about attempts to realize housing aims. However, as a whole, the interviewees had not moved very much as adults, for there were a total of $86.1 \%$ who had experienced at most three moves. In contrast to what one might believe, a positive correlation existed between homeownership and the number of moves. Homeowners independent of the form of ownership had moved more than the others in their search for a better dwelling (Table 9). Again, this phenomenon may well be explained by the Finnish housing policy, and the right it provides to deduct interest on housing debts in taxation.

A difference was also apparent among those interviewees whose homeownership was measured by the joint ownership of both spouses. Joint ownership of a dwelling and more frequent moves are related to each other. The result depicts a couple saving for a home, who increases their wealth by every now and then "capitalizing" their dwelling (Table 10).

Because joint homeownership by a married couple or a couple living in a consensual union is the most secure starting point for both spouses and for family life, this variable was cross-tabulated with the number of births. We could then see whether housing security had any effect on the birth rate. A difference did appear between those with joint ownership of a dwelling and others in regard to the number of births. Among those who had joint ownership of their home, $28 \%$ had had three or more births, while the corresponding figure for others was 22.3. In the "other" group, $37.1 \%$ of the interviewees had had one birth, while the corresponding figure among joint homeowners was only 23.1 (Table 11 ).

Regarding the result, the time factor must be borne in mind, because at least in the youngest groups, those born in 1960-64 and 1965-67, there are naturally more both of those who do not own their homes and of those who have only had one birth so far. A reliable result cannot yet be obtained for these women. Thus, in the age-

T a b l e 9. Number of moves and ownership of dwelling

$\begin{array}{lcccccr}\begin{array}{l}\text { Ownership of } \\ \text { dwelling }\end{array} & 0 & 1 & 2 & 3 & 4+ & \text { Total } \\ \begin{array}{l}\text { Joint/respondent } \\ \quad \text { sppouse }\end{array} & 24.5 & 24.2 & 21.3 & 14.6 & 15.4 & 67.7 \\ \text { Other } & 44.7 & 20.5 & 15.2 & 9.0 & 10.6 & 32.3 \\ \quad \text { Total } & 31.0 & 23.0 & 19.4 & 12.8 & 13.9 & 100.0 \\ \text { N }=4155 & & & & & & \end{array}$

$\mathrm{T}$ a b l e 10. Number of moves and joint ownership of dwelling

$\begin{array}{lcccccr}\begin{array}{l}\text { Ownership } \\ \text { of dwelling }\end{array} & 0 & 1 & 2 & 3 & 4+ & \text { Total } \\ \text { Joint ownership } & 23.2 & 25.6 & 21.7 & 14.7 & 14.8 & 53.1 \\ \text { Other } & 39.9 & 20.1 & 16.7 & 10.6 & 12.8 & 46.9 \\ \text { Total } & 31.0 & 23.0 & 19.4 & 12.8 & 13.9 & 100.0 \\ \text { N }=4155 & & & & & & \end{array}$


$\mathrm{T}$ a b l e 11. Number of births and joint ownership of dwelling

\begin{tabular}{lccccc} 
Ownership & \multicolumn{5}{c}{ Number of births } \\
of dwelling & 1 & 2 & 3 & $4+$ & Total \\
Joint & 23.1 & 48.9 & 20.8 & 7.2 & 65.2 \\
Other & 37.1 & 40.6 & 14.9 & 7.4 & 34.8 \\
Total & 28.0 & 46.0 & 18.7 & 7.3 & 100.0 \\
N $=2989$ & & & & &
\end{tabular}

1945-49 birth cohort

1950-54 birth cohort

$\begin{array}{lcccclcccc} & 1 & 2 & 3+ & \text { Total } & & 1 & 2 & 3+ & \text { Total } \\ \text { Joint } & 21.0 & 47.9 & 31.0 & 68.4 & \text { Joint } & 18.9 & 51.2 & 29.9 & 70.6 \\ \text { Other } & 34.7 & 41.8 & 23.5 & 31.6 & \text { Other } & 38.8 & 41.0 & 20.2 & 29.4 \\ \text { Total } & 25.4 & 46.0 & 28.6 & 100.0 & \text { Total } & 24.7 & 48.2 & 27.1 & 100 \\ \mathrm{~N}=674 & & & & & \mathrm{~N}=639 & & & & \end{array}$

1955-59 birth cohort

$\begin{array}{lcccr} & 1 & 2 & 3+ & \text { Total } \\ \text { Joint } & 22.1 & 52.8 & 25.2 & 65.9 \\ \text { Other } & 44.7 & 40.6 & 14.7 & 34.1 \\ \text { Total } & 29.8 & 48.6 & 21.6 & 100.0 \\ \text { N }=578 & & & & \end{array}$

$\mathrm{N}=578$

standardized examination, the difference sought between those jointly owning their home and the others had not yet been formed in the youngest age groups. On the other hand, in other childbearing age groups the difference was statistically significant. Those jointly owning their home had had more births.

An attempt was made to clarify the possible effect of the above time factor also by examining the question "In the future, do you plan to have a child or children?" according to age group and joint ownership of the home. Plans for having children did not relate significantly here, however, as they did not otherwise, to housing in its concrete aspects. As it is, we already know from other research that plans for having children are just plans and in Finnish society they are not realized to the extent that one might assume from the interviews. Plans and willingness to have a child are greater than the actual possibilities existing in everyday life. In this data, also, the average ideal number of children of those interviewed is one child more than the number of children ultimately borne (Nikander 1992a, 104).

An examination of housing size in area in different age groups does not bring out any clearly interpretable correspondence with plans to have a(another) child or children. On the other hand, in examining the correspondence between the size of the dwelling and the number of births experienced in different age groups, a significant correlation was found between these variables in the 25-45 year age group (Table 12). To the fact that the statistical correlation is present only in the middle age groups can be given a natural explanation: in the youngest age group, those under 25 , women have not yet had time to give birth or their life model now is only a one-child family in a small dwelling. In the group over 45 , women are already beginning to be past the stage of having a family with children and births or children no longer explain the size of the dwelling. Some of those interviewed already are living in the empty-nest phase.

As a whole, the examination in Table 12 shows that Finland's housing policy over the last few decades can be considered relatively successful, for adequate-sized dwellings and the families living in them have been relatively successful in finding one another. Thus quite a number of families with three or more children have already been 
Table 12. Size of dwelling (in square meters) and number of births

$1945-49$ birth cohort

\begin{tabular}{lcccr} 
& \multicolumn{4}{c}{ Births } \\
Size & 1 & 2 & $3+$ & Total \\
-55 & 52.6 & 39.5 & 7.9 & 5.6 \\
$56-70$ & 47.3 & 35.1 & 17.6 & 11.0 \\
$71-80$ & 26.5 & 45.9 & 27.6 & 14.6 \\
$81-100$ & 27.9 & 47.8 & 24.3 & 20.2 \\
$101-120$ & 15.4 & 52.0 & 32.6 & 26.0 \\
$121+$ & 16.4 & 44.1 & 39.5 & 22.6 \\
Total & 25.4 & 45.9 & 28.7 & 100.0 \\
N $=673$ & & & &
\end{tabular}

1955-59 birth cohort

\begin{tabular}{lcrrr} 
& \multicolumn{5}{c}{ Births } \\
Size & 1 & 2 & $3+$ & Total \\
-55 & 48.8 & 41.5 & 9.8 & 7.1 \\
$56-70$ & 57.1 & 31.9 & 11.0 & 15.7 \\
$71-80$ & 29.2 & 55.8 & 15.0 & 20.8 \\
$81-100$ & 20.6 & 54.2 & 25.2 & 22.7 \\
$101-120$ & 16.9 & 54.2 & 28.8 & 20.4 \\
$121+$ & 23.4 & 42.9 & 33.8 & 13.3 \\
Total & 29.8 & 48.6 & 21.6 & 100.0 \\
$\mathrm{~N}=578$ & & & &
\end{tabular}

1950-54 birth cohort

\begin{tabular}{lrrrr} 
& \multicolumn{4}{c}{ Births } \\
Size & 1 & 2 & $3+$ & Total \\
-55 & 64.5 & 22.6 & 12.9 & 4.9 \\
$56-70$ & 58.0 & 33.3 & 8.7 & 10.8 \\
$71-80$ & 22.3 & 62.8 & 14.9 & 14.7 \\
$81-100$ & 24.6 & 52.3 & 23.1 & 20.4 \\
$101-120$ & 14.0 & 50.6 & 35.4 & 27.9 \\
$121+$ & 14.7 & 44.1 & 41.2 & 21.3 \\
Total & 24.8 & 48.1 & 27.1 & 100.0 \\
N = 638 & & & &
\end{tabular}

1960-64 birth cohort

\begin{tabular}{lcccr} 
& \multicolumn{4}{c}{ Births } \\
Size & 1 & 2 & $3+$ & Total \\
-55 & 64.1 & 33.3 & 2.6 & 10.8 \\
$56-70$ & 57.9 & 35.8 & 6.3 & 26.2 \\
$71-80$ & 44.0 & 49.5 & 6.6 & 25.1 \\
$81-100$ & 26.6 & 50.0 & 23.4 & 17.7 \\
$101-120$ & 32.6 & 53.5 & 14.0 & 11.9 \\
$121+$ & 33.3 & 53.3 & 13.3 & 8.3 \\
Total & 44.5 & 45.0 & 10.5 & 100.0 \\
N $=362$ & & & &
\end{tabular}

$\mathrm{T}$ a b le 13. Number of births and number of moves

\begin{tabular}{lcccccr}
\multicolumn{7}{c}{ Number of moves } \\
Births & 0 & 1 & 2 & 3 & $4+$ & Total \\
1 & 25.4 & 26.8 & 22.3 & 12.3 & 13.1 & 28.0 \\
2 & 22.3 & 23.7 & 21.9 & 15.3 & 16.7 & 46.0 \\
3 & 19.8 & 20.5 & 22.3 & 18.4 & 18.9 & 18.7 \\
$4+$ & 23.9 & 19.7 & 20.6 & 17.4 & 18.3 & 7.3 \\
Total & 22.9 & 23.7 & 22.0 & 15.2 & 16.3 & 100.0 \\
$\mathrm{~N}=2989$ & & & & & &
\end{tabular}

able, in the course of time, to obtain a larger dwelling than the others. In all the age groups that were studied, these modern "large families" tend to move to the biggest dwellings.

A prerequisite for the success of this housing distribution has been that those who have had more children, have moved more often than the others. As the family grows, there is more pressure to find a larger home. Already among families with three children, the number of moves compared to smaller families grows significantly (Table 13). One explanation why families with many children strive to get a better dwelling and succeed in it, again probably lies in the right to deduct interest on housing loans, which as a means of raising the standard of housing has led to increased moves but indirectly also to a rise in the birth rate.

In conclusion one can note, however, that families with children still live quite modestly, when measured by the size of the dwelling. Even families with three children still live in dwellings which are at most 55 square meters in size. And among families with two children, one third still live in dwellings this small. In these families there is a definite lack of space. Thus we cannot be at all satisfied with how families with 
children are housed. Housing continues to contract the family, and this contraction is probably also affecting the birth rate.

The real-life situation still found in modern Finland of a family with children squeezing into a small dwelling, at least at first, and the image of a family with two children with really lots of room and impressive surroundings to live in are the opposite poles, between which future housing policy concerning families with children should be planned. For Finland's future housing policy and the birth rate, the image of a spacious home, which still includes a child, is significant. We should be able to raise the number of children in that home at least to two, and not just in our imagination, but in practice as well.

Therefore, although in the future nine out of ten moving into a dwelling will be households of at most four persons, at least new housing construction should already take into consideration the growing need for room, new expectations and the corresponding standards for family housing. We should also continue to look after the interests of families with children in Finland, so that they also will have the opportunity in real life to strive for quality in housing.

Apparently the same potential situation prevails concerning the ideal number of children and ideal housing. There is a great deal of attitudinal readiness for raising the level of both of them. In real life, however, the flexibility needed to realize these ideals has not been found. Nevertheless, our country should be able to utilize the existence of this potential when making decisions concerning society, if we really are still interested in constructing housing and thus possibly also raising the birth rate. Existing and future families with children apparently continue to be willing to strive to improve their own standard of housing, at the same to give birth to children and thus to produce well-being also on the societal level.

\section{References}

Juntto, A. (1993). Jatkuuko kodinomistuksen kasvu tulevaisuuden Suomessa? (Does the home-ownership increase in Finland in the future?). In: Asumisen tulevaisuus: asuntopolitiikan ja rakentamisen vaihtoehdot, edited by K. Andersson and A. Juntto, pp. 160-169. Helsinki: Asuntohallitus and Rakennusalan Kustantajat RAK.

Kivistö, T. (1993). Visioita ja kysymyksiä asumisen tulevaisuudesta (Visions and questions of future housing).In: Asuntotoimi Suomessa, pp. 267-280. Helsinki: Asuntohallitus and Painatuskeskus.

Lankinen, M. (1990). Nuorten asunnontarpeen ennakointi (Anticipating the need for housing of the young). Opiskelija- asuntoneuvottelukunta.

Lujanen, M. (1993). Asuntopolitiikan kansainvälistä vertailua (International comparison of housing policy). In: Asuntotoimi Suomessa, pp. 253-266. Helsinki: Asuntohallitus and Painatuskeskus.

Nikander, T. (1992a). Naisen elämänkulku ja perheellistyminen: the woman's life course and the family formation. Population 1992:1. Helsinki: Statistics Finland.

Nikander, T. (1993b). Suomalaisnaisen perheellistyminen (The family formation of the Finnish woman). Population 1992:10. Helsinki: Statistics Finland.

Nuorisoasuntoliiton asuntopoliittinen kannanotto (The policy stand of the Union for Youth Housing in Finland). Helsinki, May 1993.

Väisänen, P. (1992). Otanta-asetelma ja kato (Sampling and non-response). In: Naisen elämänkulku, pp. 169-172. Helsinki: Statistics Finland. 